Zdravko

Saveski

\title{
Trade Unions, Workers and the Protection of Workers' Rights: a Vicious Circle with No Escape?
}

\section{Bionote}

Zdravko Saveski (1976) is a member of Leftist Movement "Solidarity" and secretary of the Multiethnic Union of Education. He is author of "Beyond and Dilemmas" (2011). He is also coauthor of "Devaluation of Labour" (2010) and editor of "Strike: Experiences and Actualities" (2011).

\section{Abstract}

The overall problem with the trade unions, workers and protection of the workers' rights is that the workers wait for the trade unions to defend them, protect them and advance their rights, while the trade unions can not achieve that without the workers' support. Without their support, not being able to realistically threaten with a sanction, the trade union representatives go to negotiate with the owners with an empty gun, showing weakness that is simply not enough in order to successfully defend and advance workers' rights. Precisely this inefficiency of the trade unions is a reason enough for the workers to continue distrusting the trade unions. That is how the vicious circle is created.In this analysis we look at the trade unions, then at the workers, we will locate the issues, and in the final part we will offer certain ideas on how to overcome the problem. Actually, the offering of suggested solutions itself is what differentiates the counterproductive pessimistic approach from the pessimistic approach which criticizes in order to improve.

The title of this analysis is quite pessimistic. It indicates that there is a certain vicious circle connected to the protection of workers' right, created by the trade unions and the workers, from which maybe there is no escape. As a matter of principle, the pessimistic approach to things can often be counterproductive, especially when the view that there is no escape is reEveproduced when there is a burning issue, and instead of finding solutions, the discussion is reduced to lamentations to why the situation is so bad. However, this is not always the case and therefore the pessimistic portrayal of things does not necessarily end into counter-productivity. If the problems are located to be solved, then the mere locating of the problem is not an overture to lamentation, but rather a necessary initial phase of problem-solving.

The overall problem with the trade unions, workers and protection (as well as defence) of the workers' rights is that the workers wait for the trade unions to defend them, protect them and advance their rights, while the 
trade unions (even if they themselves have no additional faults) can not achieve that without the workers' support. Without their support, not being able to realistically threaten with a sanction, the trade union representatives go to negotiate with the owners with an empty gun, showing weakness that is simply not enough in order to successfully defend and advance workers' rights.

Precisely this inefficiency of the trade unions is a reason enough for the workers to continue distrusting the trade unions. That is how the vicious circle is created. The trade unions cannot do anything without the support of the workers and the workers do not give their support until they see the results of the trade unions' work. In the meantime, workers' rights are decreased with the changes in the legal provisions and violated in practice.

In this analysis we look at the trade unions, then at the workers, we will locate the issues, and in the final part we will offer certain ideas on how to overcome the problem. Actually, the offering of suggested solutions itself is what differentiates the counterproductive pessimistic approach from the pessimistic approach which criticizes in order to improve.

\section{1) A Look at the Trade Unions in Macedonia}

At the moment, in Macedonia there are four trade union confederations and at least five independent branch trade unions which are not part of trade union confederations. Trade union confederations are: Federation of Trade Unions of Macedonia [Sojuz na sindikati na Makedonija - SSM], Confederation of Free Trade Unions [Konfederacija na slobodni sindikati-KSS]; Independent and Autonomous Trade Unions of Macedonia [Unija na nezavisni i slobodni sindikati na Makedonija - UNASM] and the Confederation of Trade Union Organisations of
Macedonia [Konfederacija na sindikalni organizacii na Makedonija - KSOM]. They are all made up of branch trade unions, where the SSM has the most branch trade unions - 18. Independent branch trade unions which are not part of trade union confederations are: Independent Union of Journalists and Media Workers, Union of the Macedonian Diplomatic Service, Independent Union of the Employees of University Clinics, Centres and Clinical Hospitals and other Public Health Organisations, Union of Music and Scene Artists and Union of the Workers of Financial Organisations.

Branch trade unions in their composition have trade union organisations at the level of employees, as the main form of self-organization. In October 2009, in Macedonia, it was legally enabled for the trade union organisations at employer level, to receive the status of a legal person, ${ }^{1}$ and with that, to exist as independent syndical organisations that would not be part of a branch trade union (nor of a trade union confederation). However, after two years, in January 2012, ${ }^{2}$ this option was revoked and since then, once again it is not legally possible for a syndical organisation to exist at employer level without being part of a branch trade union. ${ }^{3}$

1 Article 23 of the Law Amending and Supplementing the Labour Relations Law, "Official Bulletin of the Republic of Macedonia, no. $130 / 09$.

2 Article 8 of the Law Amending and Supplementing the Labour Relations Law, "Official Bulletin of the Republic of Macedonia, no. 11/12.

3 At the end of 2012, there were around 2,000 syndical organisations in Macedonia. Aleksandra Filipovska "Blocking the accounts of the syndicates that failed to renew their registration", "Dnevnik", 27.12.2012, http://www.dnevnik.mk/ ?ItemID $=5768726382 \mathrm{A01D} 4 \mathrm{~F} 8 \mathrm{~F} 25135514316 \mathrm{AEB}$ 
Here, we face the first dilemma with regard to finding solutions for improving the image of trade unions in Macedonia. There is a conviction among part of those aware of the syndical realities in Macedoniathat the introduction of the possibility to have independent trade union organization on employer level was a tacticsof the government to weaken the unpromising president of the most numerous syndical union, SSM in 2009 and the abolition of this possibility in 2012 intended to strengthen the position of the trade union confederations, after replacing the unpromising president with a promising one. Aside from this tactical game with the laws, which unnecessarily wasted a lot of energy of the trade unions on bureaucratic work, is it one of the solutions for the "yellowness" and inefficacy of the trade unions in Macedonia to once again provide legal option to establish independent syndical organisations? At first glance, yes. Independent syndical organisations would not have to be members of branch unions and to give part of the membership fee for syndical bureaucracy in order to enjoy their positions with the workers money, not doing anything for the workers, even harming their interests. Iindependent syndical organisations could themselves fight for their rights with the employer and use the money from the membership fee for the benefit of the workers. Although it is very possible for an independent syndical organisation to work like this, what one has to be aware of is that in such a case two important issues appear. First of all branch trade unions and trade union confederations, due to the presence of a huge number of independent syndical organisations, would considerably weaken and with that loose part of their potential to win legal changes for the benefit of the workers. This is also important from the aspect of independent syndical organisations, because only part of the workers' problems are due to the violation of the rights guaranteed by the Constitution, laws and collective agreements by the employer. Part of the problems is due to the changing of the legal provisions where the employer, respecting the worsened legal provisions, introduces a practice in the company/institution which is damaging to the workers. The independent syndical organisations can't fight against this without cooperating with the other syndical organisations. Second, the possibility of establishing independent syndical organisations carries the danger of having two, three, four and more syndical organisations wasting energy to take over members of other syndical organisation in the same enterprise/institution, and in respect to the employer, the dividedness to be the reason for the bad efficiency.

It is false to think that the more separate trade unions there are, the more successful the representation of the workers' interests will be. This is regardless whether it concerns syndical organisations at enterprise level or branch trade unions or syndical unions. There is (significant) syndical pluralism in Macedonia, with four syndical unions and several branch trade unions. Has the representation of workers' interests improved regarding the level when there was only one syndical union? Obviously, establishing new syndical unions and independent branch trade unions is not the solution that automatically guarantees that the representation of workers' interests will improve. Of course, that does not mean that one needs to remain part of a corrupted syndical structure at any cost, but it means that splitting of the syndical movement must be the next step following the unsuccessful intention to stand in the way of corrupted and passive syndicalists.

Let's go back to the description of the syndical movement in Macedonia. Now that we know which and how many the syndical unions and independent branch trade unions are, let's see how numerous they are, i.e. how many 
employees in Macedonia are members of trade unions. Also, let's see where syndical organisation dominates.

It is difficult to even approximately determine the percentage of the workers who are trade union members. What is definite is that the percentage is low and that it is in decrease. The trade unions themselves don't usually reveal the number of their members mainly because that would indicate how weak they are and how weak they have become. The estimate (which does not have to be very precise) is that in 2014, 120,000 workers were syndically organized. ${ }^{4}$ If one has in mind that in 2013 in Macedonia there were 488,110 workers, ${ }^{5}$ then we can estimate that around 25\% of the workers in Macedonia are syndically organised. Of course, the level of union density in which only one of four workers is a member of an union can not be estimated as good, but it should be taken into account that this level of union density is better than the level of 21 of the 34 member-states of OECD. ${ }^{6}$ Macedonia has higher level of union density than Germany (17.7\%) and of all Eastern European members of OECD (Estonia, Poland, Slovakia, Slovenia, Hungary and the Czech Republic). It even has a somewhat higher

4 The estimate is mainly made on the data from Mare Ančeva who mentioned that in 2012 SSM had 76,000 members and KSS - 43,000 members. In 2013 a decrease of members is noticed in several larger branch syndicates of SSM. See "Annual reports on labour relations and the social dialogue in South East Europe for Macedonia”. http://www.fessoe.de/ srpski/annual-review-2013.html

5 This is a figure only of the employees, t.e. those that are not employers, self-employed and unpaid family workers, that are also included in the general figure of 678,838 employed persons. See State Statistics Bureau, “Anketa na rabotnata sila” [„Анкета на работата сила], 2013“, June 2014, 47.

6 OECD, "Trade Union Density", http://stats.oecd.org/Index. aspx?DataSetCode=UN_DEN level that Greece (21.3\%), the European example of an organised and militant workers' movement.

However, as with all other rankings of the countries in the world, where Macedonia is in a good position compared to the rest, there is an explanation for that which is not advantageous and that is not revealed by the statistics. Regarding the "high" level of union density, it should be emphasized that this happens, among other things, due to the pressure put on the employees to become a member of the trade unions by the state as an employer and, paradoxically, by the private owners. In both cases, the condition for that is the existence of another, at least a bit active trade union. If such a trade union exists, the state as an employer, and the private owners can start pressuring the employees to become members of the "yellow" trade union that they control in order to, by making it more numerous and representative, "negotiate" with it and make legal changes and collective agreements that realistically don't mean much to the workers. In fact, especially in the private sector, establishing "yellow" trade union and enlarging its membership by pressures, is the reserve plan of the employees for dealing with the authenthic syndical organisations. If they don't manage to prevent the workers from realising their constitutional right to form and join an union, and the workers manage to form an union with considerable power, then employers can support the already existing "yellow" trade union or even establish their own "yellow" trade union and in that manner marginalise the authenthic trade union from collective negotiation and natural growth. Not completely unimportant, membership in this type of controlled trade unions means a small, but not insignificant, decrease of the salary because that $1 \%$ of the salary that is taken for membership in the trade union goes to the employer and not to the workers, so in reality it can not be treated as part of the salary that the workers spend as they see fit. 
Speaking of union density in Macedonia, it is necessary to mention that there is a huge difference in the union density in the state sector, as opposed to the one in the private sector, where union density is greater in the state sector. Aside for that, in the private sector there is also a difference between union density in the privatised companies and the one in the originally private companies. In the privatised companies, before the privatisation, there was often syndical organisation which often continued to exist even after the privatisation of the company. That is not the case with the originally private companies where trade unions should be established a new and where, as the reality in Macedonia shows, it rarely happens. The main reason for that is that the owners position themselves above the Constitution of the Republic of Macedonia, but the size of the company is also a factor. Just like in the other countries, in Macedonia there is more often syndical organisation in the companies with more employees than in the ones with fewer employees. And originally private companies in Macedonia usually fall in the category of small and medium companies.

To complete the portrayal of trade unions in Macedonia and as a kind of introduction into the next part of the analysis, we shall determine the position of the trade unions in Macedonia in accordance with the classification of trade unions that can be made based on their dedication to the workers' cause and based on the effect of their activity. According to this classification, the trade unions can be divided into seven categories: 1) "yellow", 2) bureaucratic, 3) inactive, 4) inefficient 5) efficient, but narrowly focused 6) efficient and solidary 7) efficient and anti-system trade unions. In the first category, "yellow" trade unions, are those trade unions that have sold themselves, that don't represent the workers' interests, but are here to protect the interests of the owners or the government and to control and sway the workers. In the second category, bureaucratised trade unions are those trade unions whose leaders have not sold themselves to the other side, but who do not represent the workers' interests, only their own. The third category, the inactive trade unions are the ones for which it can not be said that they are yellow or bureaucratised, in general they want to protect the workers' rights, but they do little or nothing in reality to achieve this. The next category are the inefficient trade unions which are the trade unions that actually work on the protection of the workers' interests, but due to some reason, there is no big effect from their work. That is not a problem for the trade unions in the fifth category which are efficient in the protection of workers' rights, but are quite narrowly focused - they are interested only in their members' rights. Unlike them, the efficient and solidary trade unions not only efficiently protect the workers' rights, but also express solidarity with other trade unions and workers, and also with other associations and informal citizens' initiatives. Finally, the seventh category of trade unions is of those that are efficient and oriented against the system. They locate capitalism itself as a problem and think that in order for the workers' situation to essentially improve, capitalism needs to be replaced with another, fairer socioeconomic system.

If one has this classification in mind, we can say that the majority of trade unions in Macedonia are "yellow" or bureaucratised, that the majority of them are inactive or inefficient and only a small part of them are efficient, narrowly focused or solidary. There are no anti-capitalist trade unions in Macedonia. 


\section{2) The Lack of Trust in the Trade Unions and the Reasons for That}

The trust in trade unions is weak and in principle it is not necessary to argument that. ${ }^{7}$ Convictions such as "trade unions are not worthed", "they don't care about the workers", "they care only about their positions", "they are one with the government" are dominant in all three categories relevant for the trade unions: the general public, the workers as a whole, and the workers that are syndically organised. There is lack of trust that the syndicalists have the will to act in the interest of the workers, and when that is not questioned, there is lack of trust that they have the power to act in the interest of the workers. Where can we locate the problem related to this situation?

7 The Macedonian Centre for International Coperation in its report on the trust in Macedonia, determined that in 2010 the syndicates had the trust of only $25.3 \%$ of the respondents. From all of the state and public institutions and organisations, only the political parties had somewhat less support (23.3\%), and, paradoxically, even the employers' organisations had higher support than the syndicates (27,2\%). See, Saso Klekovski, Emina Nuredinoska, Daniela Stojanova, "Doverbata vo Makedonija” [Сашо Клековски, Емина Нурединоска, Даниела Стојанова „Довербата во Македонија“], МСМС, Skopje, 2010, p.6, http://www.mcms.org.mk/images/ docs/2011/doverbata-vo-makedonija-2010.pdf According to the same report for 2013, the support for the syndicates shows significant increase (35.9\%) and is slightly higher than the trust in the employers' organisations (35.6\%). However, the increase of the distrust in almost all state and public institutions and organisations throws a shadow on the complience with scientific standards in this research. See Aleksandar Krzalovski [Александар Кржаловски], "Doverbata vo lugjeto I vo instituciite” [„Довербата во луѓето и во институциите”] 2013 (Skopje: MCMC, 2013), http://www.mcms.org.mk/images/ docs/2013/doverba-vo-lugjeto-i-vo-instituciite-2013.pdf, accessed on August 2013
At first glance, the fault is at the top. The fish stinks from the head. That is definitely true in certain cases, but not always. In general, the reasons for the unsuccessfulness of the trade unions can be located in all four concerned factors: the central syndical management, the syndical representatives, the ordinary trade union members and the unorganized workers. The central trade union management (branch union or trade union confederation) can be "yellow" and/or bureaucratised, not actually doing anything for the workers and acting as an arm of the government aimed at controlling and swaying the workers. However, it can have completely honest intentions and be blocked in its activities by the lack of interest and the apathy of the ordinary members of the trade union. Syndical representatives, i.e. the trade union presidents at the level of enterprises/institutions can be sold, can deal with the owner/employer, use their position as an additional basis for getting extra payment, and nothing more than that. Even if this is not the case, they can, which is also unacceptable, care only about new years' parcels and pork halves. But on the other hand, union representatives can be the most active syndicalists in the enterprise/institution who are completely dedicated to fighting for workers rights and are ready to dedicate significant time for that purpose and put themselves at additional risk. Concerning the ordinary syndical members, they can be watch dogs of the corrupted syndical representatives, but they can also be uninterested in anything, to avoid and to wait for someone else to do the job for them. In the end, the unorganised workers may be unorganized because they can't manage, due to the pressure from the employer, to establish or to be members of a trade union, or they do not want to be members of a corrupted trade union at their workplace, but they can also refuse to be members of a trade union because they are taking the side of the owner, wanting to get the rights without effort, or they simply do not believe in the efficacy of collective actions. 
It is easiest to blame the union leadership. However, in order to support the blame with arguments, one must first check whether the problem is not with the syndical representatives, the ordinary members and the unorganised workers. Even the best central union leadership can not do much if it is not supported by syndical representatives, if the regular members are passive and if a large number of workers stay aside from syndical actions. All those who criticise must first ask themselves whether they have done what is required of them. This is the golden rule, which, unfortunately, is rarely applied. Concerning the trade unions in Macedonia, the problems are not only at the level of the central union leadership, but also at the level of syndical representatives, ordinary members and unorganised workers. It shows that the problems with the trade unions will not be solved by just putting the "right people" to lead the trade unions.

If we want to speak more precisely, the reasons why the trade unions are so weak in Macedonia are the following:

a) Low union density. As we have already mentioned, union density is about $25 \%$, it is decreasing and even this percentage is realistically lower, due to the forced memberships in "yellow" trade unions of a certain number of workers.

b) Lacking mobilisation potential. When the ruling party, VMRO-DPMNE, requires of its members to get involved in a certain partisan activity, the response of the members is huge. Maybe the best example for that was the signing for the candidature of the old-new president Gjorgje Ivanov last year. Not only did the members crowded the offices of the State Electoral Commission, but they did't waste time to do that. We will not comment at this point what the mobilisation potential of VMRO-DPMNE is due to. We will only mention that the trade unions in Macedonia are not even close to such mobilisation potential. There is a lack of identification with the trade unions both among the members and the rest of the workers. It is not rare for syndical members not to know which trade union they are members of. As a consequence of the lack of identification of the members, the mobilisation potential of the trade unions is very small. Union leaderships seriously doubt that members of their trade union, not to mention the rest of the workers, will participate in their actions (protest, strike, May Day event etc.), therefore they avoid calling them to take part in such actions, even when they themselves think they should be done.

c) Weak moral integrity of the syndical leaders. Aside of a few exceptions, the trade unions are dominated by people that either sold themselves to the other side or care much more about their positions than the defence of the interests of the workers that they represent.

d) Low level of intra-syndical democracy. Again, except for a small number of cases, democracy is just a proclaimed value in the syndical documents. The number of "eternal" syndical functionaries is not small and there are examples of syndical leaders that hold the same position more than 20 years. Someone may have contributed much to their trade union, but if he/she has made himself/herself irreplaceable, then he/she has not managed to create a healthy trade union. In context with the topic of trade unions and democracy, we would only shortly add, with respect to horizontal organisation typical for the leftist organisations in Macedonia, that, although horizontal organising is an important democratic step forward, it should not be recommended to the trade unions. Horizontal organisation has its 
advantages, but its disadvantages as well. The main disadvantage is the vulnerability to takeovers. In syndical context, that would mean that the minority dedicated fighters for workers rights within a trade union could be overruled by the majority of workers acting in accordance with the employer's directions. Aside for that, within the syndical movement, it must be insisted that the decision of the majority must be obligatory for all members. If the opposite is allowed, that everyone should decide whether to participate in a certain action, as he/she finds fit, it will additionally weaken and disable effective syndical actions.

e) Unconditional commitment to social dialogue. It is certainly better to succeed in achieving workers' rights through negotiations than through confrontation. But what if social dialogue can not be achieved through social dialogue? For many trade unions, that is where the fight ends. Simply, if they don't manage to protect the workers interests through dialogue, they give up on taking further steps. What they fail to understand in that process is that the voluntary abdication from "confrontation" measures due to the blind ideological dedication to the "dialogue" is exactly what limits the negotiating power of the trade unions. For a trade union to be successful in the social dialogue with the other "social partners", it must have negotiating power. That negotiating power greatly depends on the ability of the trade union to mobilise the workers to strike or protest in case the employees or the state do not want to fulfil its requirements. Because of that, the negotiating power of the trade union is necessarily dependable on its protesting power. If the trade union limits itself to social dialogue, it cuts the branch it is sitting on. The trade union can manage to achieve the fulfilment of its demands through social dialogue only if it has the capacity to mobilise a larger number of workers to protests and strikes, in case they are not fulfilled. If it lacks that capacity, or even worse, if it deprives itself from that capacity, then the position of the trade union in the social dialogue can easily be neglected by the other side.

f) Orientation towards defensive strategy. Due to the orientation of all governments in Macedonia and the employers to decrease workers' rights and violate them in practice, the trade unions are forced to use a defensive strategy, to protect the existing rights and to demand their implementation in practice. This fight for defending workers' rights is so long that it seems as if the trade unions have forgotten to complement their defensive strategy with an offensive one, and aside for defending existing rights, to require introduction of new rights. Limited to only a defensive strategy, the trade unions allow the other side to define the public discourse which instead of introducing a new right, concentrates on the defence of a right that is going to be decreased or abolished.

g) The trade unions are typical Macedonian institutions with Macedonian mentality. Complaining and lamenting have unfortunately become a national sport in Macedonia. The huge majority of people often complain and lament without trying to change the situation that they are complaining and lamenting about. This complaining and lamenting are so widespread among Macedonian citizens, as well as the insisting that their problems are the greatest; one could easily think that maybe the passion of Macedonians is greater than the one of Christ! Then, these troubles are treated as an excuse enough not to take action. The Macedonian syndical representatives are not the exception from the typical 
image of the Macedonian citizen. It often happens, when two Macedonian syndical representatives meet, both of them to explain to each other which and what kind of unsurpassable problems there are in their own syndical activities and what king of obstacles he/she is faced with. Even when trying to guide the discussion in the direction what, aside for the limitations, can be done, the discussion again and again returns to the issue of the obstacles due to which not even the slightest steps can be taken to change the situation. A good syndical representative is honest and dedicated, but also brave. Surely, one should not go head on, but courage is definitely required, to encourage the other members of the trade union as well, and having in mind all the limitations and risks that appear on the path of syndical action, to succeed in the intention to defend and advance workers' interests.

h) Dealing too much with issues of secondary importance. Part of the syndical activities, undoubtedly important in conditions of considerable impoverishment of the workers in Macedonia, is the provision of collective consumer discounts for the trade union members. That is not a problem in itself, but it becomes a problem when the whole syndical activity of the union is restricted only to New Year's parcels and pork halves. That practice is so widespread that part of the uninformed citizens think that the trade union is an organisation that deals only with that, New Year's parcels and pork halves. Per definitionem.

i) The nonexistent or insufficient visibility of the positive aspects of union activities. The trade unions provide free legal assistance to their members, they have solidarity funds for non-refundable monetary assistance and loans without interest for their members, they manage to protect some workers' rights that the government wants to decrease/ abolish, and sometimes they manage to press some boss to respect and advance workers' rights. However, the wider public and the workers are little aware of these rare successes and qualities in the work of the trade unions. Part of the problem is that the trade unions themselves do not dedicate enough attention to the informing of the public, and the other part of the problem is that most of the media does have the will to inform about the positive aspects of the union activities.

j) Turning trade unions into geriatric organisations. The average age of the syndical members is quite high, especially the one of the syndical leaderships. That is a disadvantage for every organisation. Therefore, as the years pass, the danger of that organisation dying becomes even more real. Although some trade unions have their youth organisations (usually trade union confederations, not the branch unions), they are passive, insufficiently involved in the syndical activities and not aware enough of the current issues of young workers. They are more of an ornament than new blood in the trade union. Although we mentioned this problem of the trade unions of Macedonia last, it is the one that is threatening to become their greatest problem.

\section{3) Workers and How they (Don't) Protect Their Own Rights}

The defending and advancing of workers' rights definitely depends on the trade unions, but also on the workers. As mentioned above, without the support of the workers, the trade union can not seriously threaten the employers (the owners and the state) with sanctions in case they refuse to fulfil the syndical/workers' requests. The workers are also one of the factors from which the status of the workers' rights depends. It can therefore not be expected from all others, and especially from the 
trade unions, the Labour inspectorate and the political parties, to defend and to advance workers rights, while the workers sit with folded arms. Not only is it morally problematic someone to expect others to fight for their right, without that person giving his/her contribution, but also the other factors often can not manage to achieve someone's rights, even when they really want it, without the contribution of the person concerned.

It is important to underline that the strength of the trade union does not depend only on the union leadership, but on the members as well. Not only the union leadership has to be dedicated to the cause, but the ordinary members as well. The inactive, bureaucratic, and so on, leadership makes the trade union passive, but so do the apathetic members as well. For example, a strike can not be successful with five or six people, however dedicated to the cause they might be. That is why it is difficult for a trade union to be able to complete the task. The leadership should be good, but so should be the members. If only one of the sides has a problem (meaning, the leadership or the members), the trade union shall be unsuccessful.

In Macedonia, not only do the workers have complaints against the syndicalists, but the syndicalists have complaints against the workers. One of the better syndical activists in Macedonia has said that with this kind of workers, even if the best syndicalists in the world would come to Macedonia, they couldn't do anything. It is important to mention that this kind of perception has an effect on the trade unions themselves, i.e. on the amount of pressure that they are prepared to put on the employers.

For everyone that is openly on the side of the workers is uncomfortable to talk badly about the workers. However, without pointing out to the problem, as the first step in overcoming it, no progress will be made. Defending and advancing workers' rights definitely requires overcoming the typical mentality of the workers in Macedonia, therefore, it is necessary to talk about the problems on behalf of the workers.

a) Being unaware of one's own rights and lacking interest of learning about them. The typical worker in Macedonia is not acquainted with his/her rights, and even more, does not want to get to know them. Everything else is more interesting than that: football, Turkish series, the name dispute, the abuses of government. The legal language that the workers' rights are communicated in can be difficult to understand, the laws are changed all too often, but all of these can not be regarded as sufficient reason because it concerns issues that directly affect their lives. Aside from that, if the situation in the company/institution is generally good or acceptable, especially if the salary is regularly paid, then, the typical worker in Macedonia is not very interested in whether and which of his/her rights are respected. If it worsens, then the interest rises, but even in that case it is only a concern about one's own rights at the workplace. That the workers' rights can worsen or improve by changing the laws, that it is possible, through influence of political parties, to achieve improvement of his/her workers' rights - is something that the other people should deal with. Concerning the workers' rights of others, there is a readiness to express empathy (if an acquaintance is concerned), but solidarity is something that is simply unthinkable. Typically, 1st May is perceived as the day when we have a barbeque with our family and friends, not as a day to express dissatisfaction from the status of one's own rights and request for them to be advanced.

b) Passively awaiting help from outside. The typical worker does not see himself/herself as a factor on which his/her workers' rights depend upon and 
expects all others, especially the trade unions and the Labour Inspectorate, to serve them their rights on a silver platter. $\mathrm{He} /$ she is usually extremely dissatisfied from the efforts and the effects of the activities of the trade unions and the Labour Inspectorate, he/ she does not identify political parties as a factor that the status of the workers' rights depends upon, even though, especially when they are in power, have significant power to change the legislation to the advantage or the disadvantage of the workers, and the same is true for his/her own self-perception as a factor that his/her rights depend upon. Very often it happens that the workers exclude themselves as the guilty party for the worsening of their rights and do not include themselves as actors that can improve their rights. It turns out that everyone else is guilty, but them.

c) Taking those that are worse than them as role models, not those that are better. This feature stems from the self-exclusion as a factor of protection and advancement of one's own workers rights, as well as from the tendency to get what one is looking for with minimal personal engagement. In a trade union that does not have "yellow" or bureaucratic leadership, especially when there are syndical actions, such as strikes and similar, the president of the trade union is the busiest, and then follows the rest of the syndical management, and then, the ordinary members. If those lower down in the syndical hierarchy start taking those that are worse than them as role models, instead of those that are better than them, then the syndical actions will probably be destined to fail. Taking those that are worse as role models happens when the other members of the syndical leadership see how the ordinary members are less engaged than them, instead of looking at the syndical president, and when the ordinary trade union members see how the unorganised workers can without effort and risk get the rights for which they, the members, engage themselves, instead of looking at the engagement of the syndical leadership.

d) Feeling enormous fear. Without any doubt, the workers have enough reasons to feel fear at the work place, from losing their job to lowering the salary and the rights if they try to organise their co-workers to protest against some unacceptable practice of the owner. Due to the high unemployment rate, many workplaces became precarious, uncertain, therefore uncertainty related to the danger of losing job is felt not only by those who are not officially registered as employed, those who are engaged as freelancers, and those that have atypical employment contracts, but also those who have typical employment contracts are de facto precarious workers. However, it is necessary to underline that the feeling of fear can often go beyond reason and become a phobia. Surely it is reasonable for all that are not gamblers to refrain from taking action, if the risk from taking a certain action is $90 \%$. No normal syndical or workers' activist would urge workers to go head on and to act as it is fit to act in vacuum. However, when the risk of consequences for defending ones' rights is 10\% and even less, the worker that refrains from taking action, or from joining one, in order to protect his/ her rights becomes a phobic worker. In Macedonia, unfortunately, not only do we have a serious problem because a great percent of the workers are precariat, but also because a significant part of them is phobiat.

e) Nurturing false hope. In general, hope is a positive feeling. However, it can instigate action, but it can also block it. If someone has a hope that life can be better than today, then it can motivate that person to help the establishing of a more acceptable reality than the current one, regardless whether it is on a 
micro or macro level. The destruction of this type of hope is the reason why the losers of the system largely accept their present situation, although it is to their disadvantage. The typical worker in Macedonia not only lacks this hope, but is inclined to nurture false hope: that the boss will have an understanding for their suffering, that the boss, by definition, working for his/her own benefit, works for the benefit of the employees as well, that things will take care of themselves, there is no need for him/her (the worker) to interfere and to put himself/herself at unnecessary risk. The outcome of this kind of reasoning is almost always: worsening of the workers' situation and getting crumbs from the boss. However, because of self-pity, rationalisation of one's own passivity and believing the boss' propaganda, these crumbs often are enough for the workers not to rebel. This is because hope that things will take care of themselves in the future is strong.

f) The feeling of powerlessness and distrust in the collective action. The typical worker in Macedonia feels powerless, hopeless. Not only does he/she not believe the organisations and the institutions supposed to help him/her (the trade unions and the Labour Inspectorate first of all), but he/she does not believe in his/her own strength. So, not believing that it is possible to change the situation which is bad and is getting worse, the workers contribute to the worsening of their own situation. The axiom of workers' organisation - that one worker is weak opposed to one owner, but that all the workers together are not - is usually regarded as a nice fairytale. The typical worker is not only unready to solidarise, to take action, for example, when a coworker unrightfully loses his job, but has also lost his faith in collective action. Convinced that collective resistance against the owner can not be organised (due to colleagues' snitching, their fear and/or apathy), even when the worker thinks that it is possible, he/she does not believe that it is possible to achieve something through collective action. What the owner is faced with is a mass of atomised workers that have lost their faith in collective opposition, and in such case it is easy for him to violate their rights.

g) Having no class awareness. Lastly, but equally important, it should be mentioned that the class awareness of Macedonian workers is low. This is true for both the "real" workers and the other ones, of which many (for example, university professors) do not consider themselves as workers, although they work for a salary. Even when there is one, it is what Vladimir Lenin calls trade-unionist, i.e. syndicalist awareness, which shows interest only for the most immediate problems not for the general problems of the working class and its ability to change society. The low awareness of the workers in Macedonia is in the deep shadow of ethnic belonging, which the workers in Macedonia, as the rest of the population, regard as their primary, and even the only identification.

\section{4) What is To Be Done?}

As one can see, the vicious circle situation in which the trade unions and the workers find themselves in is quite bad and results with open space for the other side to continue decreasing and violating workers' rights. If one of the factors, the trade unions or the workers, is at the necessary level, then there are chances that it could result in an effective resistance to further violation and decrease of the rights. But, as we have seen, there are serious problems both concerning the trade unions and the workers. The syndicalists, faced with the apathy and passive endurance of the workers, feel unmotivated 
to fight for their rights, and the workers, passively waiting for someone else to solve their problems, have considerably lost trust that the syndicalists are ready to help them, and when they have that trust, that they actually have the capacity to help them.

In this kind of situation, it is easiest to give up on the whole project and passively wait for the moment when everything just becomes too much and when the workers riot spontaneously, not because they want to, but because they simply have to. However, all of this is an unsatisfactory and unacceptable "tactics" for all who have engaged themselves on the side of the workers, motivated both by personal interest and dedication. Therefore, in continuation, several suggestions will follow about what should be worked on in order to break the vicious circle that the trade unions and the workers are caught up in.

a) Gradual improvement of things both with trade unions and the workers, but mainly with trade unions. Trade unions are the ones called to break the vicious circle. No matter how many weaknesses the workers may have, no matter how present the feeling may be that workers do not deserve the dedication of the syndicalists, the trade unions are organised entity and because of that, can more easily prepare action plans. Futhermore, the reason for their existence is the protection of workers' interests, so they are called, however difficult it may be, to earn the money that they get from the workers' salaries as membership fees. What is needed in the first place is to reinstate the workers' trust that the syndicalists want to improve their position. If (when) that trust is established, the trust that they are able to help (or that they are at least working on developing their abilities) should be reinstated.

b) Building an offensive strategy. So far, trade unions were concentrated (almost exclusively) on defending workers' rights. That must be changed. The reason for that is not only because in the meantime many rights were abolished or decreased, and there is continuously less rights left to defend, but because concentrating exclusively on a defensive strategy (as in all spheres) means tying your own hands. It is necessary to determine the key demands for improving the current situation of the workers and, in that sense, to start focussing, to make campaigns for their realisation. Usually, the situation is such that it is necessary to improve workers' rights in many spheres. In such a situation, the trade unions equally work (or don't work) in all these spheres. The workers do not know what their representatives are doing and what are their proposals. That is why it is necessary to determine the key demands, to inform the workers why the focus is on them and to try to realise them.

c) Networking and cooperation of the non-"yellow" trade unions. In Macedonia, advancement in this direction was made in 2013 with the signing of the Syndical Charter by several branch trade unions, a trade union confederation and two organisations that are particularly into defending workers' rights. Among other things, in 2014, they held a successful protest on May Day and came out with a list of three key demands. The cooperation between the signatories of the Syndical Charter continued further on and in the future it should be extended, and eventually other trade unions should be included.

d) Forming syndical organisations in more companies and institutions. Many companies, especially the originally private ones, are without syndical organisations. It is necessary to establish contact with the employees in the companies without syndical organisation and to try to organise the workers in those companies. 
e) Not hiding the criticism aimed at the workers. When dealing with workers, it is necessary not to hide the things that are problematic in their behaviour, that actually hinder their involvement in the defending of their labour rights. It is necessary to underline that it is neither possible nor morally correct everyone else to deal with their rights, except they themselves; it should be stressed to them that they sometimes fear too much even when the risk from the consequences is not so high; it is necessary to warn them not to nurture false hope, etc. No one likes hearing bad things about one. Therefore, when the syndical and workers' activists mention this type of things, there is a risk that the worker might build a negative image for them. However, if problems are not acknowledged, they simply can not be solved. Defending workers' rights and their advancement is not possible without involving the workers in that struggle. That is why syndical and workers' activists must take the risk of mentioning negative things, even at the price of workers having an impression that they are not on their side. Hoping that the workers will recognize who really works for their benefit.

f) Making workers believe in themselves. Workers do not believe in their own strength and they do not believe in efficient collective action. Their faith in both must be restored. This can be helped by positive examples of defence of workers' rights, especially through workers' collective action. These examples are maybe not many, but they exist, should be identified and transferred to the workers, to serve them, aside for all the differences, as examples and inspiration.

g) Participation of the leftists in the establishing of trade unions and taking their entry in already established ones. The leftists, who by definition are on the side of the workers, should not only defend workers' rights by principle and from outside, but, when they are employed, they should try to form a syndical organisation in their work places or, if there is a syndical organisation, to become part of it. Establishing of a syndical organisation is not at all easy and is not always possible, not due to the lack of engagement by the leftist, but due to the lack of interest or passivity of the co-workers. In such a case the leftist should try to create a climate for establishing a syndical organisation and, when there is a serious violation of the rights, to try to organise the co-workers. In cases when there is already a syndical organisation at his/her work place, unless it is a "yellow" trade union, the leftist should get involved in his/her work and help the union to become better and more efficient. If the union is "yellow", then he/she should work on the establishing of a new syndical organisation. The employed leftists in Macedonia, unfortunately are not involved enough in the trade unions. They often have the same negative opinion about the trade unions, as the other workers. Experience shows that, in the cases when they got involved, it happened that they often came upon a positive feedback from the syndicalists. That is why no assumptions should be made, but conclusions should be made based on personal experience whether a certain trade union is "yellow" and closed or not. Maybe the example with the entry of the Communists in the so called URS unions in the 1930's can serve as a relevant example. Although they had many remarks on the work of the URS unions, especially for their leadership, by the end of the 1930's the Communists in Macedonia massively joined these trade unions and became prominent workers' activists and strike organisers. Many of them later join People's Liberation Army during the World War Two and gave their lives for a brighter future. 